\title{
Medical Imaging of Mummies and Bog Bodies - A Mini-Review
}

\author{
Niels Lynnerup \\ Laboratory of Biological Anthropology, Department of Forensic Medicine, University of Copenhagen, \\ Copenhagen, Denmark
}

\author{
Key Words \\ Mummy · Bog body · Paleopathology $\cdot$ CT scan • \\ Radiography
}

\begin{abstract}
Mummies are human remains with preservation of nonbony tissue. Mummification by natural influences results in so-called natural mummies, while mummification induced by active (human) intervention results in so-called artificial mummies, although many cultures practiced burial rites which to some degree involved both natural and artificial mummification. Since they are so uniquely well-preserved, mummies may give many insights into mortuary practices and burial rites. Specifically, the presence of soft tissues may expand the scope of paleopathological studies. Many recent mummy studies have focused on the development and application of non-destructive methods for examining mummies, especially radiography and CT scanning with advanced $3 \mathrm{D}$ visualizations. Indeed, the development of commercially available CT scanners in the 1970s meant that for the first time the 3D internal structure of mummies and bog bodies could be studied non-destructively. This article describes the history of mummy radiography and CT scanning, and some of the problems and opportunities involved in applying these techniques, derived for clinical use, on naturally
\end{abstract}

and artificially preserved ancient human bodies. Unless severely degraded, bone is quite readily visualized, but accurate imaging of preserved soft tissues, and pathological lesions therein, may require considerable post-image capture processing of CT data.

Copyright $\odot 2009$ S. Karger AG, Basel

By definition, mummies and bog bodies are human (or animal) remains with preservation of non-bony tissue. Depending on mortuary practices, the natural environment and the time span since death, soft tissue preservation may be excellent or very poor, and there really is no exact boundary line between a skeleton with some preserved soft tissue (skin remnants, ligaments, etc.) and a mummy. However, the word mummy is generally used when soft tissue preservation is so pronounced that body parts, or the whole body, have somewhat intact skin and some preserved internal structures such as muscle fasciae, ligaments and maybe even tissue of internal organs and muscle [1].

Soft tissue is preserved when the postmortem conditions are such that the usual tissue degradation, including the action of bacteria and insects, is hindered. At its most basic, this is a question of tissue dehydration overtaking tissue postmortem decay. This may be achieved either

\section{KARGER \\ Fax +4161306 1234 \\ E-Mail karger@karger.ch}

www.karger.com
(C) 2009 S. Karger AG, Basel

0304-324X/10/0565-0441\$26.00/0

Accessible online at:

www.karger.com/ger
Niels Lynnerup

Laboratory of Biological Anthropology, Panum Institute

Blegdamsvej 3

DK-2200 Copenhagen N (Denmark)

Tel. +45 3532 7239, Fax +45 3532 7215, E-Mail n.lynnerup@antrolab.ku.dk 
naturally due to environmental conditions such as a hot or very cold, dry climate, or it may be facilitated by mortuary practices that in a fashion mimic these environmental conditions, such as removal of internal organs and drying out of body cavities. Mummification by the former influences hence results in so-called natural mummies, while mummification induced by active (human) intervention results in so-called artificial mummies. The word mummy itself is derived from the old Persian word, mumeia, or mum (Arabian: mumiya) for bitumen or pitch. Medicinal properties were ascribed to this substance which flowed from the Mummy Mountain in Persia [2]. Since mummies often presented themselves as blackened or dark due to the desiccation of the skin, it was thought that bitumen and asphalt were materials used by the ancient Egyptians in their mummification processes (spanning the time period of ca. $3000 \mathrm{BC}$ to the Roman era), so the word came to designate embalmed bodies [2].

Mummies and bog bodies present unique opportunities for many scientific fields. Since they are so uniquely well-preserved, both natural and artificial mummies may give specific insights into mortuary practices and burial rites. This may also be due to a parallel preservation of associated artifacts like clothing, tools and utensils. The mummified body itself may reveal body ornamentation, such as tattoos and details on hair style, etc. The presence of soft tissues may expand the scope of pathological studies, so that more acute diseases and diseases which do not affect bone tissue may be identified [3, 4]. The mummification and preservation of the various soft tissues, though, is very variable. Interior organs, particularly of the digestive system, are often completely decomposed, and organs may be very shrunken and difficult to identify morphologically due to desiccation. Furthermore, various funerary rites comprising embalming and evisceration may entail the complete removal of internal organs and the brain. Generally, the soft tissues most often preserved are tissues with a high content of collagen, like the dermis, muscle fasciae and tendons. Still, even just the presence of skin may give important clues to pathology and trauma, e.g., penetrating wounds and cuts, scars and even warts. Better soft tissue preservation may also be indicative of good aDNA preservation, perhaps also allowing identification of pathogen DNA. Finally, gut contents may also be seen, allowing for detailed paleodietary studies, which may complement stable isotope-based studies [1].

However, the very presence of soft tissue, especially the skin, at the same time makes it difficult to examine the body. One may conduct an 'autopsy', but while such mummy autopsies have often been carried out $[2,4]$, most archaeologists, conservators, and indeed osteologists and pathologists, are not always too enthusiastic about this. An autopsy is an invasive and destructive procedure, meaning that the integrity of the mummy or bog body as an archaeological specimen may be destroyed. The attitude has perhaps shifted from an earlier more clinical, medical approach to mummies (in a certain sense seeing the body as any other unidentified body which must be properly examined in a forensic way) to one of recognition that a mummy is an invaluable archaeological artifact. This has meant that more emphasis is being placed on the development of non-destructive methods for examining mummies, including especially radiography and CT scanning with advanced 3-dimensional visualizations $[1,5]$. Noninvasive procedures also mean that the mummified body is kept intact, i.e. the bodily integrity is upheld, a valuable point in cases where there are ethical considerations, e.g. reverence for the dead.

When discussing X-rays and CT scanning of mummies, there is sometimes the question of whether MRI is also an applicable method for mummy investigations. By far most mummies are completely desiccated, which rules MRI out (as MRI is dependent on hydrogen ions, i.e. water). However, recently in a preliminary study, Rühli et al. [6] have shown that MRI may in fact be possible without rehydration.

\section{X-Rays and Mummies}

The most well-known noninvasive technique for visualizing the internal structures of mummies and bog bodies employs X-rays. Indeed, the first use of X-rays in mummy research occurred only one year after William Röntgen discovered X-rays in 1895 [7]. Petrie [8] used Xrays in his studies of Egyptian mummies in 1897. Moodie [9] published the findings of his analyses of 17 Egyptian mummies at the Field Museum in Chicago in 1931; this probably constitutes the first systematic X-ray analysis of a major mummy collection. All the royal mummies housed at the Cairo Museum were X-rayed in 1967 [10, 11]. X-raying of mummies has also been performed onsite in some very remote locations $[12,13]$.

The primary focus of X-raying mummies has often been archaeological as well as medical; e.g., searching for amulets in Egyptian mummy wrappings. However, the determination of sex and age, based on skeletal traits, has usually been carried out whenever possible [14]. Smith 
[15] judged the epiphyseal union of the mummy of Tuthmosis IV in order to ascertain age at death. Cranial traits and cranial morphometry based on X-rays have been studied in order to try to establish kinship [11]. This preempted one of the uses of CT scanning: the production of 3D solid models of skulls for facial reconstruction purposes (see below). Neave [16] managed to make a facial reconstruction of an Egyptian mummy based on radiographs.

The pathological changes observed by X-raying mummies include arthritis, atheroma, healed fractures, and parasite-induced changes $[11,17,18]$. Most of the pathological processes observed reflect diseases affecting bone or calcified structures, such as a radiodense structure which, at a later autopsy, was revealed to be a guinea worm parasite. This is a reflection of the limitations of $\mathrm{X}$-rays. Skeletal structures are usually easily identifiable due to the high attenuation, but it may be very difficult to discriminate between various soft tissue remains, especially as these will be superimposed on top of each other on the X-ray film. The skin and fasciae of the ventral aspect of a mummy will thus be superimposed over the remains of interior organs and interior membranes and fasciae, as well as the skin and fasciae of the dorsal aspect. Since the soft tissues may already have nearly equal attenuation coefficients, this greatly inhibits the possibilities for investigating soft tissue pathology.

\section{CT Scanning}

A further development of X-raying came with the advent of CT scanners (fig. 1). Unlike conventional X-ray images, the regions of interest in CT scannings are presented without disturbing superimpositions of juxtaposed structures [19].

CT scanning of mummies was first carried out in 1977 $[20,21]$. Eleven mummies at the Museum of Fine Arts in Boston were CT scanned by Marx and d'Auria [22] in what was then the most systematic CT scanning of a collection of mummies. The increasing computing power enabled imaging with an ever finer resolution and rapid $3 \mathrm{D}$ visualizations $[23,24]$. Basically, the CT scanner computer 're-stacks' the single slices and, based on different algorithms, connects object boundaries between the slices [25]. CT scanners used in hospitals come equipped with various computer programs which allow rapid image building and $3 \mathrm{D}$ visualization, but it must be noted that the software is developed for medical purposes, and tuned to tissues and organ systems of the living. For ex-

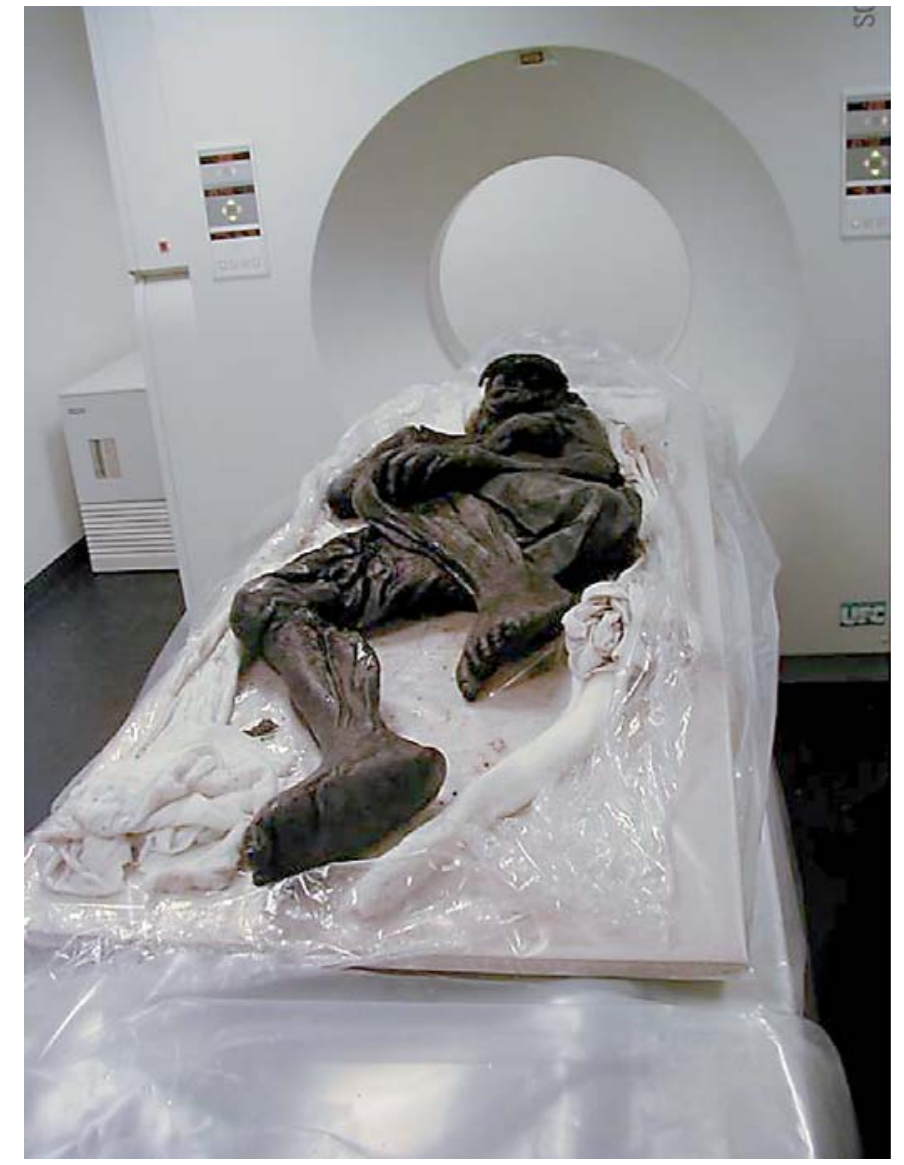

Fig. 1. CT scanning of the Borremose Woman (photo: N. Lynnerup).

ample, the Hounsfield units associated with living bone do not vary much (pathology and very thin bones aside), so it is easy to pre-program a $3 \mathrm{D}$ rendering of the skeletal tissues in a CT scanner, so that, e.g., the skull of a scanned patient can be visualized just by a click on the appropriate menu. Mummies, and especially bog bodies, may require much more work at this stage (see below). Large, detailed studies on embalming techniques and mummy wrappings of Egyptian mummies (fig. 2), also employing 3D imagery, have lately been performed by Hoffman et al. [26].

Recently, three Inca mummies were found on top of Mount Llullaillaco, the highest mountain in Argentina. Due to the extreme height, the 500-year-old mummies were frozen. This meant that the internal organs were exceptionally well-preserved, and easily visible upon CT scanning [27].

The benefits of 3D visualization also apply to the assessment of possible pathological changes. For example, 


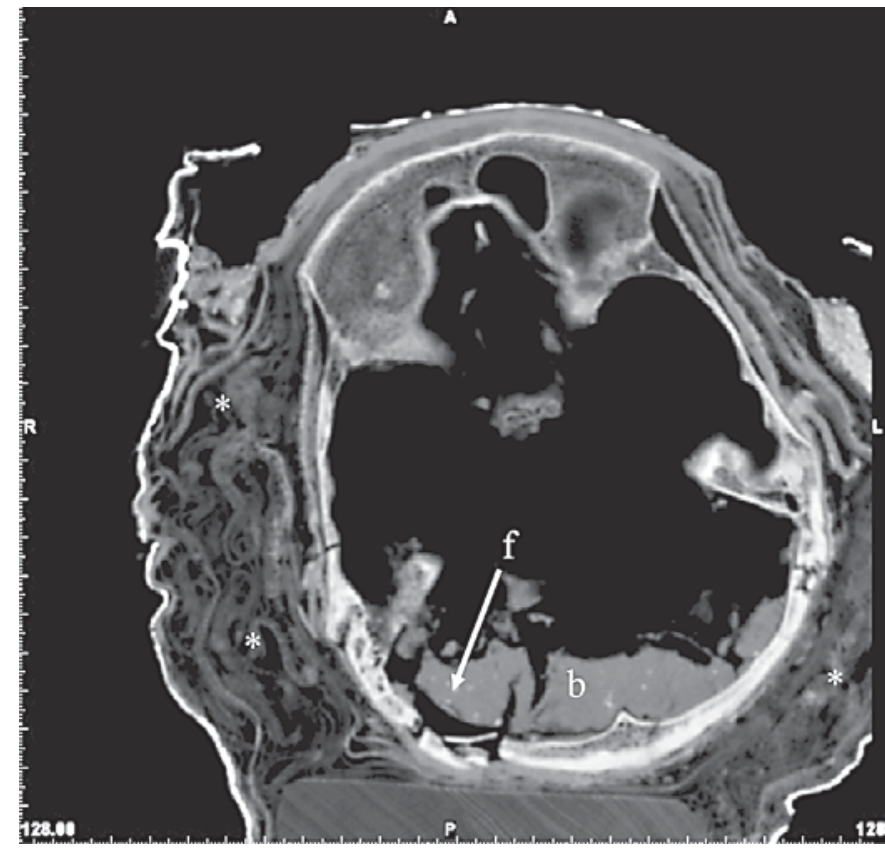

Fig. 2. A single slice through an Ptolemaic Period Egyptian mummy (Carlsberg Gyptotek Museum, Copenhagen, Denmark). The many layers of wrapping are clearly seen (marked by asterisks). The scan is of the head, and the cranial vault is clearly seen. The brain has been removed as was customary for the embalming techniques (although there are some remains in the back of the vault, marked ' $b$ '). This was done through the nasal aperture and ethmoid, and the bony structures in this area were indeed fractured (not shown in this figure). Since the brain has been removed, the CT scanner renders the cranial cavity black. The skull fracture seen in the back of the vault occurred postmortem (marked 'f').

a mummy which had already been scanned in 1983 [28] was re-scanned in 1990 in order to make 3D visualizations of the skull and pelvis to confirm a possible fracture [24]. Dental disease has also been visualized in this way [29], as has an Egyptian mummy where an intravital foreign object (presumably a toe prosthesis) was found [30]. However, given all the mummies which have been CT scanned, pathological or traumatic finds have been rather sparse. Probably one of the more well-known cases involved the CT scanning of the Iceman, a glacier mummy dating back some 3,000 years, found in Italy in 1992. The mummy had been X-rayed and CT scanned after the find [31]. However, not until a renewed scanning 10 years later was an arrowhead identified in the left shoulder region [32]. Rheumatoid arthritis has been diagnosed based on CT-visualized bone erosions and joint subluxation [33]. A CT scan of a natural mummy from the 19th century, found in an ancient friary in Italy, revealed a distended bladder and a ring of dense tissue at the site of the prostate, indicative of prostatic hyperplasia [34]. Bone tumors have been identified in two Egyptian mummies [35]. Bone pathology as observed by CT scanning, indicative of tuberculosis, has been correlated with aDNA analyses [Pap, personal communication].

It should be mentioned that CT scanning has also been used to locate pathological processes or specific organs in order to make precise incisions to perform biopsies [36] or to guide endoscopic examinations [37].

\section{Problems in Mummy and Bog Body CT Scanning and 3D Visualization}

The presence of many layers of mummy wrappings, especially those closely adhering to the skin, as well as organ removal, etc., may impede interpretation of the body structures of a mummy. Diagenetic changes, mainly desiccation, may also have an impact. However, in both natural and artificial mummies, the skeletal structures are usually intact. This means that structures useful for aging and sexing may still be visualized. Availability of the skeletal images also results in having many 'point de repere', which makes it easier to assess remains of internal organs and structures.

Special problems of X-raying and CT scanning arise when the diagenetic changes are so massive that the remaining tissues, including bone, are severely degraded. This is perhaps best shown by bog bodies, all of which date to the northern European Iron Age (approximately $500 \mathrm{BC}-500 \mathrm{AD}$ ). X-rays and CT scans share two major differences between bog body and clinical images. Due to the acidic bog environment, calcium is leached from the bones, causing a demineralization of the bony tissues, which consequently lose their hardness and become pliable [38]. When a bog body is X-rayed, bones are often very badly visualized. The bones appear as though they were made of glass. This may be demonstrated by the Xrays taken of the Grauballe Man, a Danish bog body from the Iron Age, excavated in 1950 and X-rayed in 1955 [39]. Consequently, CT scanning a bog body (and applying the same range of Hounsfield units for bones, as for clinical work) may result in the bones not being visualized at all. Furthermore, the demineralization is not necessarily uniform, but may differ within the skeletal system or the single bone due to the diagenetic microenvironment. This may generate a patchy appearance of the bone, even though it is intact morphologically (fig. 3). The second 
Fig. 3. The skull of the Tollund Man (right) and the Grauballe Man (left). Note the impressions in the parietal region due to diagenesis (softening of the bone due to loss of mineralization, so that it bends under soil pressure).
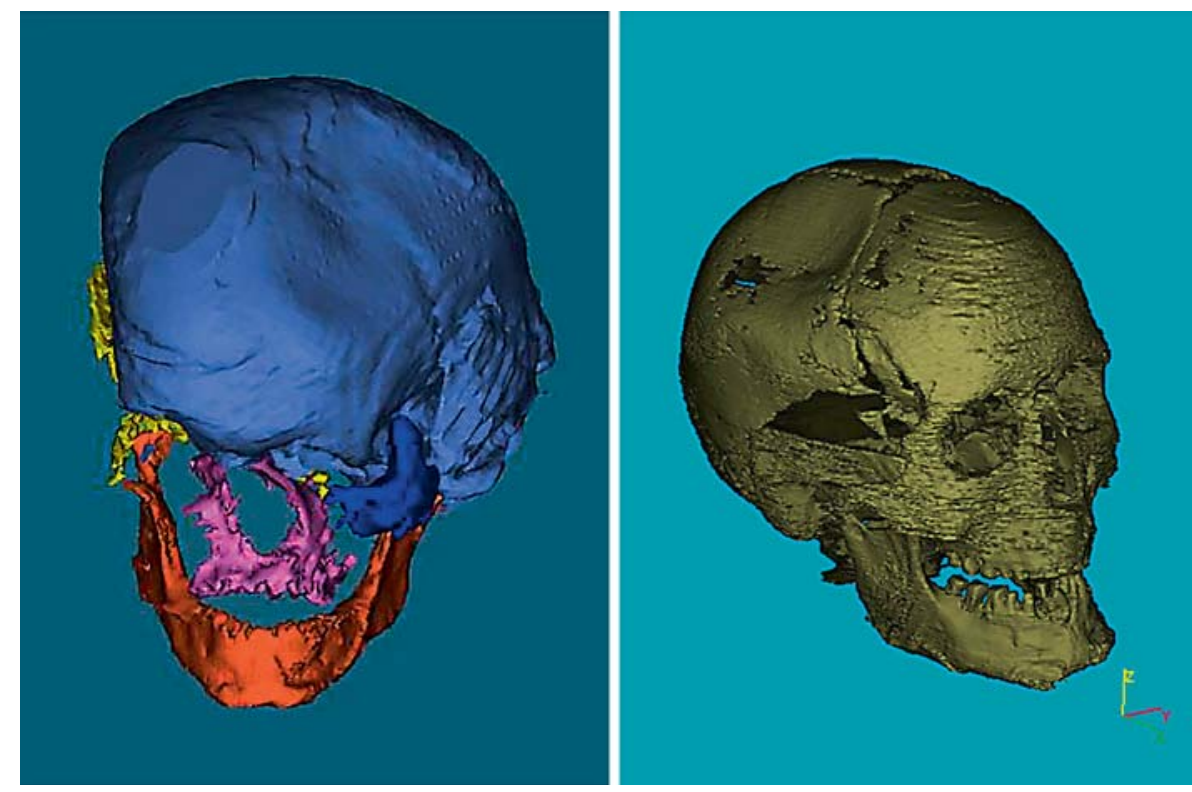

difference is the fact that other tissues seem to acquire a more radiodense structure (i.e. the attenuation of the Xray beams is increased). This is especially seen in some of the connective tissues, e.g. ligaments, fasciae and the subcutis. The reason for this is probably a deposition of soil mineral salts (containing metals as iron) in collagenous tissues [39]. The extent to which the bog environment may have an effect on bog bodies can be illustrated by our work on three such recently found bog bodies from Ireland (Clony Cavan Man, Old Man Croghan, and Derry Cashel; results to be published). These bog bodies have recently been subjected to a series of scientific studies, including CT scanning. The head of Clony Cavan Man shows extreme lateral flattening, with a facial breadth of only approximately $2-3 \mathrm{~cm}$. The humeri of Old Man Croghan are an example of differential preservation: the right humerus is intact enough to be readily recognizable, while the left humerus is very difficult to visualize.

Many bog bodies are also shrunken. While some shrinking may take place in the bog, most shrinkage is probably due to the drying out of the bog bodies when they are excavated. Drying out was previously the only preservation and conservation method to handle excavated 'wet' bog bodies. In the mid-20th century more targeted methods were used, such as attempts to substitute the water with alcohols and tannic oils, bark extracts and wax, while today freeze-drying is used. Whatever the method, some shrinkage is probably inevitable, but may be pronounced especially for the older bog finds [39].

Medical Imaging of Mummies and Bog Bodies
Thus, diagenetically modified tissues and organs may have to be delineated (or segmented) manually on almost every single slice. At present, features allowing manual slice-by-slice image editing are seldom available on the computer programs of the (clinical) CT scanners. The images therefore need to be transferred to another program which allows editing (post-processing) of the CT data [5].

\section{Post-Processing of CT Scan Images}

Several computer programs exist that allow post-processing of the CT data, especially the very important ability to manually edit the single image slices. In order to visualize, e.g., the head of the Grauballe Man, color coding is applied 'over' the single gray scale pixels. The color coding is done simply to discern different tissues, organs and structures, much akin to anatomy illustrations. This usually involves a process of identifying the single structures on the single slice images and then following these structures through on the adjacent slices. For example, the bones of the skull may first be picked out, then the brain, etc. All the single slices have to be edited, so that ultimately the individual structures are completely delineated (segmented). The color-coded pixels associated with the various structures may then be extracted, and used as a basis for $3 \mathrm{D}$ rendering of specific tissues and structures [1]. 


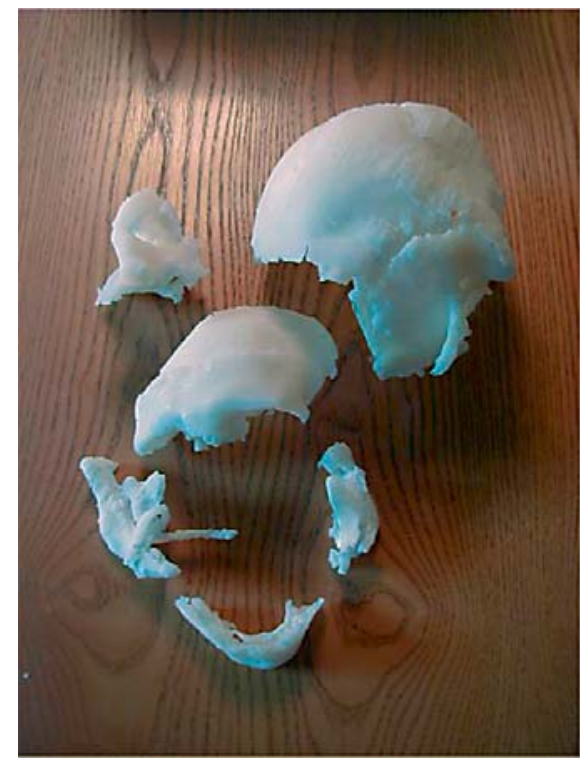

Fig. 4. Stereolithographic models of the cranial bones of the Borremose woman.

The manual process of delineating and extracting the relevant items (tissues, organs, etc.) necessitates a certain anatomical knowledge, even more so as the bones are often bent and deformed and organs are often shrunken. There is some room for subjectivity when performing segmentation. Along with the previously stated caveat on slice thickness (and indeed on the inherent properties of $\mathrm{X}$-ray-based image acquisition), this means that CT scanning images and $3 \mathrm{D}$ renderings should not be viewed as a totally objective and 'true' representation of internal structures and tissues. Some pathological processes may be falsely ascribed to diagenetic processes, while some diagenetic processes may be misinterpreted as pathological processes [1].

Once tissues and organs have been segmented and visualized, they can then be measured and assessed morphologically.

\section{Pathology and Pseudopathology}

Our examinations using CT scanning of the bog bodies has meant that we were able to visualize otherwise hidden structures, and the editing after image acquisition further allowed us to visualize demineralized bone. This in turn allowed us to reappraise some of the previously described lesions. Acid bog diagenetics mean that

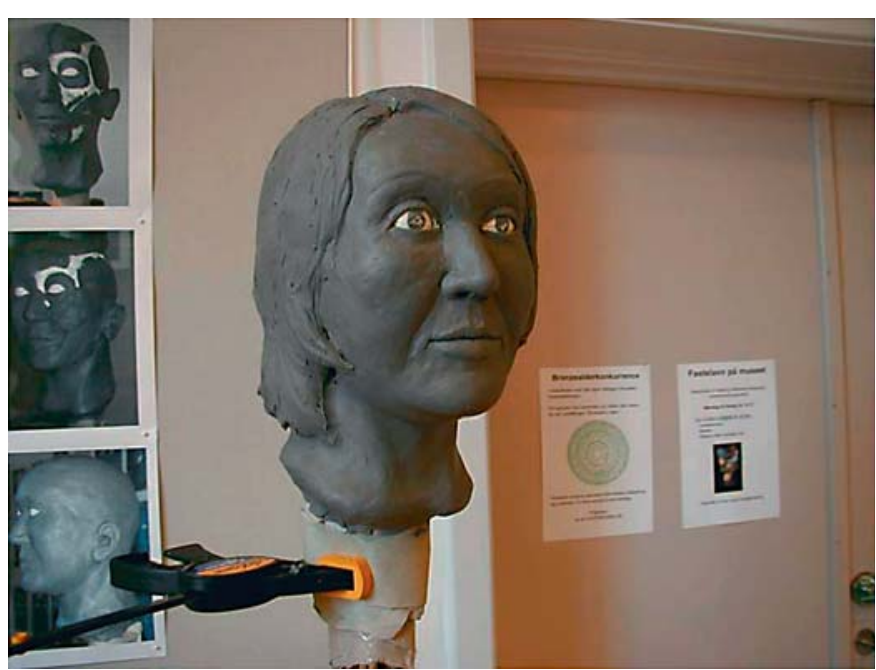

Fig. 5. Facial reconstruction of the Borremose Woman (photo: N. Lynnerup).

bone will be demineralized, become pliable and, upon subsequent excavation and drying out, also shrink and warp. This means that, under these conditions, etiological attribution of pathology and trauma lack certainty.

Paleopathological finds are overall sparse, especially in non-mineralized tissues. And for those pathological conditions identified, it may perhaps be discussed to what extent minor pathologies have a major impact on biocultural understanding; trauma, however, is clearly indicative of an active, maybe even sacrificial, cultural setting. The Tyrolian Iceman had an arrow point lodged in his shoulder [32], while nearly all the bog bodies have definite signs of having been put to death [38].

Attempts to establish guidelines for segmenting images, producing $3 \mathrm{D}$ visualizations, and to address taphonomic influences as well as observer error is underway [Rühli, personal communication].

\section{Conclusion}

The methods of CT scanning and subsequent 3D visualization are powerful analytical tools for paleopathological and physical anthropological analyses of mummies and bog bodies. The technique allows the visualization of internal structures, especially bone and teeth. However, post-processing is often necessary to extract 
the full information from the CT data. This is especially the case with bog bodies, where there is much taphonomic alteration of the skeletal structures. We have CT scanned several Danish bog bodies and, based on our findings, we feel that some lesions, previously claimed to be signs of perimortem trauma, may have to be reevaluated. Due to the sometimes extreme postmortem diagenetic influences on the bog bodies, it may be impossible ever to be certain on the exact nature of the observed lesions.

Finally, we wish to draw attention to the fact that CT scanning may not only be a valuable analytical tool, but also an extraordinarily precise tool for documenting bog bodies and mummies. The CT-scanning process generates data, literally millimeter by millimeter and inside out, in a digital format that may be accessed and shared with other scientists or museums. Our cooperation with Argentine scientists in the investigation of the Mount Llullaillaco Mummies is an example of such a data shar- ing. The CT-scanning data may also be important in terms of future assessments of the preservational status of the bog bodies. Using so-called stereolithography, it is possible to produce 1:1 models of CT-scanned structures directly from the computer visualizations [30, 40, 41], detailing structures at a $1-\mathrm{mm}$ resolution (fig. 4). This has some very evident uses for exhibits, and has been used as basis for facial reconstruction of mummies and bog bodies (fig. 5). Aside from advances in resolution and faster CT scanners, future prospects will probably include more CT-scanned bog bodies and mummies that will lead to better comparative studies. These can be expected to result in a better understanding of mummification, taphonomical changes, pseudopathologies, and the nature of observed lesions and tissue preservation. In this respect, the use of CT scanning in mummy studies as a 'screening tool' for locating pathological changes for subsequent precise sampling or for guiding endoscopic procedures will probably become more common.

\section{References}

1 Lynnerup N: Mummies. Am J Phys Anthropol 2007(suppl 45):162-190.

2 David AR, Tapp E: Evidence Embalmed. Manchester, Manchester University Press, 1984.

3 Cockburn A, Cockburn E, Reyman TA: Mummies, Disease and Ancient Cultures. Cambridge, Cambridge University Press, 1998.

4 Aufderheide A: The Scientific Study of Mummies. Cambridge, Cambridge University Press, 2003, p 608.

5 Lynnerup N: CT-scanning and 3D visualisation of mummies and bog bodies; in Pinhasi $\mathrm{R}$, Mays S (eds): Advances in Human Paleopathology. Chichester, Wiley \& Sons, 2008, pp 101-120.

6 6 Rühli FJ, von Waldburg H, Nielles-Vallespin S, Böni T, Speier P: Clinical magnetic resonance imaging of ancient dry human mummies without rehydration. JAMA 2007;298: 2618-2620.

7 Koenig W: 14 Photographien mit RöngtenStrahlen. Leipzig, Johann Ambrosius Barth Verlag, 1896.

8 Petrie WMF: Deshahesh 1897: Fifteenth Memoir of the Egyptian Exploration Fund. London, Egypt Exploration Fund, 1898.

9 Moodie RL: Roentgenologic Studies of Egyptian and Peruvian Mummies. Chicago, Field Museum of Chicago, 1931.

10 Harris JE, Weeks KR: X-Raying the Pharaohs. Chicago, Schribner \& Sons, 1973.

11 Harris JE, Wente EF: An X-Ray Atlas of the Royal Mummies. Chicago, Chicago University Press, 1980.
12 Notman DNH, Anderson L, Beattie OB, Amy R: Arctic paleoradiology: portable radiographic examination of two frozen sailors from the Franklin Expedition (18451848). Am J Roentgenol 1987;149:347-350.

13 Notman DNH, Beattie OB: The paleoimaging and forensic anthropology of frozen sailors from the Franklin Arctic expedition mass disaster (1845-1848): a detailed presentation of two radiological surveys; in Spindler K, Wilfing H, Rastbichler-Zissering E, zur Nedden D, Nothdurfter H (eds): Human Mummies: A Global Survey of their Status and the Technique of Conservation New York, Springer, 1995, pp 3-8.

14 Fawcitt RA, Jarvis H, Isherwood I: X-raying the Manchester mummies; in David R, Tapp E (eds): Evidence Embalmed. Modern Medicine and the Mummies of Ancient Egypt. Manchester, Manchester University Press, 1984.

15 Smith GE: The Royal Mummies. Cairo, Catalogue General des Antiquitees Égyptiennes de Musée du Cairo, 1912.

16 Neave RAH: The reconstruction of skulls for facial reconstruction using radiographic techniques; in David AR (ed): Science in Egyptology. Manchester, Manchester University Press, 1979.

17 Bloomfield JA: Radiology of Egyptian mummy. Australas Radiol 1985;29:64-66.

18 Brothwell D, Sandison AT: Diseases in Antiquity. Springfield, Thomas, 1967.
19 Hsieh J: Computed Tomography. Principles, Design, Artifacts, and Recent Advances. Bellingham, SPIE Press, 2002.

20 Harwood-Nash DC: Computed tomography of ancient Egyptian mummies. J Comput Assist Tomogr 1979;3:768-773.

21 Lewin PK, Harwood-Nash DC: Computerized axial tomography in medical archaeology. Paleopathol Newsl 1977;17:8-9.

22 Marx M, D’Auria SH: CT examination of eleven Egyptian mummies. Radiographics 1986;6:321-330.

23 Marx M, D’Auria SH: Three-dimensional CT reconstructions of an ancient human Egyptian mummy. Am J Radiol 1988;150: 147-149.

24 Pickering RB, Conces JF, Braunstein EM, Yurco F: Three-dimensional computed tomography of the mummy Wenuhotep. Am J Phys Anthropol 1990;83:49-55.

25 Zollikofer CPE, Ponce de León MS: Virtual Reconstruction. A Primer in Computer-Assisted Paleontology and Biomedicine. New York, Wiley \& Sons, 2005.

26 Hoffman H, Torres WE, Ernst RD: Paleoradiology: advanced CT in the evaluation of nine Egyptian mummies. Radiographics 2002;22:377-385.

27 Previgliano CH, Ceruti C, Reinhard J, Araoz FA, Diez JG: Radiologic evaluation of the Llullaillaco mummies. Am J Radiol 2003; 181:1473-1479.

28 Vahey T, Brown D: Comely Wenuhotep: computed tomography of an Egyptian mummy. J Comput Assist Tomogr 1984;8:992-997. 
29 Melcher AH, Holowka S, Pharoah M, Lewin PK: Non-invasive computed tomography and three-dimensional reconstruction of the dentition of a 2,800-year-old Egyptian mummy exhibiting extensive disease. Am J Phys Anthropol 1997;103:329-340.

- 30 Nerlich AG, Zink A, Szeimies U, Hagedorn HG: Ancient Egyptian prosthesis of the big toe. Lancet 2000;356:2176-2179.

31 zur Nedden D, Wicke K: Der Eisman aus der Sicht der radiologischen und computertomographischen Daten; in Höpfel F, Platzer W, Spindler K (eds): Der Mann in Eis. Innsbrück, Innsbrück University, 1992, pp 131148.

-32 Gostner P, Egarter Vigl E: Report of radiological-forensic findings on the Iceman. J Archaeol Sci 2002;29:323-326.
33 Ciranni R, Garbini F, Neri E, Melai L, Giusti L, Fornaciari G: The 'Braids Lady' of Arezzo: a case of rheumatoid arthritis in a 16th century mummy. Clin Exp Rheumatol 2002;20: 745-752.

34 Fornaciari G, Ciranni R, Ventura L: Paleoandrology and prostatic hyperplasia in Italian mummies (XV-XIX century). Med Secoli 2001;13:269-284.

35 Taconis WK, Maat GJR: Radiological findings in the human mummies and human heads; in Raven MJ, Taconis WK (eds): Egyptian Mummies. Radiological Atlas of the Collections in the National Museum of Antiquities in Leiden. Turnhout, Brepols, 2005.

36 Brothwell D, Liversage D, Gottlieb B: Radiographic and forensic aspects of the female Huldremose body. J Dan Archaeol 1990;9: 157-178.
37 Rühli FJ, Hodler J, Böni T: CT-guided biopsy: a new diagnostic method for paleopathological research. Am J Phys Anthropol 2002;117: 272-275.

38 van der Sanden W: Through Nature to Eternity. The Bog People of Northwest Europe. Assen, Drents Museum, 1996, p 200.

39 Asingh P, Lynnerup N: Grauballe Man. Århus, Århus University Press, 2007, p 351.

40 Hjalgrim $\mathrm{H}$, Lynnerup $\mathrm{N}$, Liversage $\mathrm{M}$, Rosenklint A: Stereolithography: potential applications in anthropological studies. Am J Phys Anthropol 1995;97:329-333.

41 Cesarani F, Martina MC, Grilletto R, Boano R, Roveri AMD, Capussotto V, Giuliano A, Celia M, Gandini G: Facial reconstruction of a wrapped Egyptian mummy using MDCT. Am J Radiol 2004;183:755-758. 